plumage characteristics and other relevant details. A $5 \times 3 \mathrm{~cm}$ map of America shows the summer and winter ranges.

"Warblers" covers 37 species plus one hybrid in some detail. An additional seven vagrant species and one race (the Yellow-rumped "Audubon's" Warbler) are covered by brief comments and a single accompanying photograph.

"Sparrows" includes 25 species covered in full and 20 vagrant species. In addition to the North American sparrows (buntings) this volume includes longspurs, finches, grosbeaks, crossbills, snow bunting and house sparrow.
There are two features used by this author that will make this book particularly valuable to beginners. The first is called a cheat sheet and lists all the birds in groups according to a key characteristic - such as an unstreaked breast. The birds are further grouped by a second characteristic such as a breast spot. The second, and even better innovation, is a series of comparison tables. These consist of a set of photographs with birds in similar poses. The page is arranged to show the most similar birds close together. For example, there are three Common Redpoll photographs immediately above three equivalent Hoary Redpoll photographs. Similarly, all the rufous-capped sparrows are

on one page. I think the arrangement of the warbler comparison table is very clever. Here the Mourning Warbler photograph is adjacent to a Connecticut Warbler photograph. In turn, the Connecticut is above a

photograph of a Nashville Warbler, which in turn is above a Northern Parula. All four birds share similar combinations of colour and cause confusion to the novice. This arrangement allows for easy comparison, either up and down or across the rows. For the warblers there are tables showing the spring and fall plumages. These features are on fold-out sheets at the end of the book, making them quickly available in the field. At the front of the book is a seasonal distribution list for Point Pelee National Park. Using line thickness the author also indicates the abundance of each species. I find such distribution lists to be extremely useful.

These then are two small, portable books that deal

\section{Birds of the Yukon Territory}

Edited by P. H. Sinclair, W. A. Nixon, C. D. Eckert and N. L. Hughes. University of British Columbia Press, Van- with birds that many find difficult to identify. The text is well written. The photographs are both beautiful and illustrative. Any one who needs help with the species covered will find these books a tremendous help. Perhaps we can encourage the author to write a third book on shorebirds.

ROY JOHN

2193 Emard Crescent, Ontario, K1J 6K5 Canada

couver, British Columbia.

My appetite for a long-overdue return trip to the Yukon has been incredibly whetted! This book is not just

an atlas, but also a coffee table book, a very useful bird reference, and a source necessary for a planning a trip to the Yukon. This book has stunning photographs throughout, and not just of birds, but of

dramatic scenery (i.e., habitat shots) that will make birders and non-birders alike think, "I must go there."

Prior to the species accounts, there are chapters covering the environment, aboriginal use of birds, conservation, history and a month-by-month overview of birdlife. There is also a short chapter outlining the data management for the more than 160000 records that were used.

Each species account spans one to three pages. All species are illustrated by a line drawing and at least one, sometimes several, colour photographs; frequently, there is a very good habitat shot as well. Each account also has a distribution map, and a histogram outlining the number of database records for each week of the year. The base layers of the maps show major roads and rivers as well as ecozones; I would have liked to see the dominant population centers marked as well though.

The text is thorough and reads well. All the expected sections are there (distribution, nesting, habitat...), and, where appropriate, a section on aboriginal use of the bird is included. Several appendices and a 600+ reference list end the book.

The items that bothered me were few, and mostly minor. Noteworthy was the absence of birding essays, a feature I first saw in Birds of Delaware, and thought added spark to the thick reference book. Page numbers were located in the most irritating choice possible, 
along the inner margin of each page, thus not permitting a rapid flip-through while searching through this 600 page book. The final, and dare I say incomprehensible feature of the book was the uninteresting and

out of focus (soft focus?) cover shot of the Territorial bird, the Common Raven. People do judge a book by its cover, rightly or wrongly, and in a book with hundreds of stellar shots, I remain baffled as to why that particular shot was chosen to be most people's first impression of the book.

Overall though, this is a very, very good book, and a must-have for people interested in the birdlife of the North.

RANDY LAUFF

Department of Biology, St. Francis Xavier University, Antigonish, Nova Scotia B2G 2W5

\section{Literature Cited}

Hess, G. K., R. L. West, M. V. Barnhill III, and L. M. Fleming. 1999. Birds of Delaware. University of Pittsburgh Press. 635 pages.

\section{BOTANY}

\section{Wild Flowers of the Yukon, Alaska \& Northwestern Canada, $2^{\text {nd }}$ Edition}

By John G. Trelawny. 2003. Harbour Publishing Co. Ltd., P.O. Box 219, Madeira Park, British Columbia V0N 2H0 Canada. 224 pages. $\$ 24.95$.

The first edition of this wild flower book was published in 1983 and I reviewed it in 1984. The layout in this new volume is much better. The type is larger and more spaced on a purely white paper and is wrapped around the absolutely beautiful colour photographs.

Many of the pictures of the 332 species treated are the same as those in the first edition but the more modern reproductions and paper have made them shine. The descriptive text for each species has been only slightly revised. The surrounding text includes Acknowledgments, an easy-to-read map, an Introduction, an Illustrated Glossary, a Key to Species using Flower Colour and Shape, Photo Credits, Bibliography, an Index, and a list of Additional Field Guides from Harbour Publishing. This is a most interesting and delightful book for anyone living in, visiting or planning to visit this wonderful area.

WILLIAM J. CODY

Biodiversity, Program on Environmental Health, Agriculture and Agri-Food Canada, Wm. Saunders Building, Central Experimental Farm, Ottawa, Ontario K1A 0C6 Canada.

\section{Wild Flowers of Field \& Slope in the Pacific Northwest}

By Lewis J. Clark. 2002. Harbour Publishing, P.O. Box 219, Madeira Park, British Columbia V0N 2H0. \$9.95.

\section{Wild Flowers of Forest \& Woodland in the Pacific Northwest}

By Lewis J. Clark. 2003. Harbour Publishing, P.O. Box 219, Madeira Park, British Columbia V0N 2H0. \$12.95

\section{Wild Flowers of the Mountains in the Pacific Northwest}

By Lewis J. Clark. 2003. Harbour Publishing, P.O. Box 219, Madeira Park, British Columbia V0N 2H0. \$12.95.

These three books contain absolutely beautiful colour photographs. The photographs are numbered sequentially and each one has a marker $[\times 0.5]$ to indicate its size. Each is accompanied by a printed paragraph with the common and scientific names, a detailed description, together with the habitat and range, and a number to indicate its sequence in the book. There are 108 in the first book, 100 in the second and 106 in the third. 